\title{
Beata Bilicka
}

ORCID: https://orcid.org/0000-0002-1223-4889

Nicolaus Copernicus University, Torun, Poland

\section{Professional Advancement of RE Teachers in the Context of the Challenges of the Information Society}

\begin{abstract}
In the first years of political transformation in Poland starting in 1989, one of the crucial issues was the reform of education, including changes in the procedure of professional advancement for teachers. At that time, it was also important for the Catholic Church to restore Religious Education in schools, which returned to the state education system in the 1990-1991 school year. Since then, RE teachers have had the same rights and obligations as teachers of compulsory subjects and undergone the same professional advancement procedure. Twenty years have passed since the new procedure of career progression for teachers was introduced in Poland. Therefore the author of the article attempts to answer the following questions: To what extent does the procedure meet the challenges of the information society and in what direction should it evolve due to the rapid development of information and communication technology in the world?
\end{abstract}

\section{Keywords}

Information society, RE teacher, advancement of teachers. 


\section{Introduction}

Many historians and political scientists claim that the year 1989, and in particular the first, although not fully free, parliamentary election, which took place on June $4^{\text {th }}$, allowed Poles to embark on a new stage of social, political, economic and cultural development. The systemic transformation and radical changes in all spheres of society's life also required a comprehensively planned and executed reform of the education system. Its aim was to respond to civilizational challenges on a global, European and national scale as a long-term and in-depth transformation process in the field of national education ${ }^{1}$, which was a consequence of the "civilizational breakthrough characterized by the transformation of the current post-industrial society to the conditions and requirements of the information society which focuses on the development of knowledge in all areas of human activity." ${ }^{2}$ Preparation of young Poles to function in the information society has become an important task, which, in turn, requires from teachers, including teachers of religious education, the development of information and communication competences. These competences are understood as the ability to use modern sources of information, efficient application of various types of digital devices, and the demonstration of the right attitudes towards the challenges of the information society.

The pragmatics of teachers' professional development became a significant issue related to the education reform in Poland in the period under discussion. The consequence of the changes in Polish education introduced by the Act of 25 July 1998 on amending the act on the education system ${ }^{3}$ and the Act of 8 January 1999 which introduced the reform of the school system ${ }^{4}$ were changes related to the procedure of professional advancement for teachers. They were introduced by two legal acts: the Teachers' Charter Act ${ }^{5}$, amended by the Act

${ }^{1}$ Cf. M. Zalewska - Bujak, Udział nauczycieli w przemianach edukacyjnych przełomu XX i XXI stulecia w Polsce, Katowice 2010, p. 35.

A. Górski, Procesy powstawania, przetwarzania i wykorzystywania wiedzy w społeczeństwie informacyjnym, "Studia Informatica Pomerania" (2017) No 4, p. 19.

Act of 25 July 1998 amending the School Education Act, Journal of Laws 1998, No 117, item 759 .

Act of 8 January 1999 - The School System Reform Act, Journal of Laws 1999, No 12, item 96.

The Teachers' Charter Act of 18 February 2000, Journal of Laws 2000, No 19, item 239. 
of February 18, 2000 and the Regulation of the Minister of National Education of August 3, 2000 on the career progression of teachers. ${ }^{6}$

Twenty years have passed since the new professional advancement procedure for teachers was introduced in Poland. At this point, it seems pertinent to raise the following questions:

1. To what extent does the procedure for the professional advancement of RE teachers after the political transformation in Poland meet the challenges of the information society?

2. In what direction should this procedure evolve due to the rapid development of information and communication technology in the world?

As no research has been carried out in this regard so far, it appears justified to discuss this topic in detail given the relevance of the issue.

\section{Context - Information Society}

It is difficult to clearly define what the information society is and what its components are. This term functions in almost all areas of modern life and its various aspects are analyzed from different perspectives, hence it may be defined differently. The multitude of definitions leads to attempts at their classification and thus, Tomasz Goban-Klas, for example, offers five groups of definitions of the information society taking into consideration technical, economic, professional, spatial and cultural criteria ${ }^{7}$. Similar difficulties arise when we try to look for the genesis of this term. Some researchers see its origin in the works of Fritz Machlup from the 1950s, for example ${ }^{8}$, others in the studies of Japanese scholars Tadeo Umesao, Kenichi Koyama, and Yuji Maruda. An important issue that Marian Golka draws attention to is the lack of agreement as to the legitimacy of using the term information society due to the functioning of other expressions which try to describe new phenomena such as, knowledge society, network society, computerized society, post-capitalist society, excess society,

\footnotetext{
${ }^{6}$ The Regulation of the Minister of National Education of 3 August 2000 on the Acquisition of Teachers' Professional Titles, Journal of Laws 2000, No. 70, item 825.

Cf. T. Goban-Klas, Społeczeństwo informacyjne i jego teoretycy, in: W drodze do społeczeństwa informacyjnego, J. Lubacz (ed.), Warszawa 1999, p. 30.

8 Cf. T. Goban-Klas, P. Sienkiewicz, Społeczeństwo informacyjne: szanse, zagrożenia, wyzwania, Kraków 1999, p. 52.
} 
technological society and cyber society. Golka emphasizes that the most popular term is the information society as a mental shorthand, which synthetically defines the most important features, mechanisms of functioning and effects of global phenomena we are witnessing. ${ }^{9}$ It is not my intention to resolve the aforementioned question, which is why in this paper the understanding of the term information society present in the works of the majority of authors will be applied. The condition for the functioning of such a society is the production, collection and circulation of information, and the computer, the Internet and all digital techniques are for its members one of the most crucial aspects of life and work..$^{10}$ For the information society it is important to connect computers with means of communication, which makes it possible to process information and communicate on a global scale. ${ }^{11}$

The issue of the information society is broadly understood as it encompasses all people who have access to the new media. A characteristic feature of our time are digital communication possibilities, which not only increasingly affect traditional means of communication, such as writing and speaking, but also changes in the functioning of social bonds. This, in turn, leads to new phenomena which exert influence on religious education. Some of them should be stressed at this point: the speed of information flow referred to as "spatial simultaneity of information flow"; the ability to communicate at any time and in any place, which causes compression of time and space or "media globality"; the appearance of so-called virtual reality; transformations in the manner of speaking and creative expression (hypertext, graphic simulation, multimedia, etc.); the presence of hypertexts, which alters the understanding and functioning of the sender and recipient of the text; a multitude of sources of information which may be false, manipulated, and lead to disinformation; the necessity to constantly learn how to use the latest digital devices; the presence of religion in the Internet (described by Pope Benedict XVI as a "digital continent"); the disappearance of the border between the private and public sphere, inter alia, through our presence in cyberspace. However, the most important issue regarding shifts that are taking place in the information society is, according to Golka,

9 Cf. M. Golka, Czym jest społeczeństwo informacyjne?, "Ruch Prawniczy, Ekonomiczny i Socjologiczny" (2005) No 4, pp. 253-255.

${ }^{10}$ Cf. M. Golka, Czym jest społeczeństwo informacyjne?, "Ruch Prawniczy, Ekonomiczny i Socjologiczny" (2005) No 4, p. 255.

11 Cf. T. Goban-Klas, P. Sienkiewicz, Społeczeństwo informacyjne: szanse, zagrożenia, wyzwania, Kraków 1999, p. 53. 
the emergence of a new type of community called the virtual community and the appearance of a new type of human being, sometimes referred to as homo informaticus, who may have an exaggerated awareness of the role and effects of information circulation in everyday life. ${ }^{12}$

The widespread use of information technology is also gradually affecting education systems, bringing not only important and positive aspects, but also having negative effects. Agnieszka Siemińska - Łosko indicates some of them, such as students' health problems as a result of computer abuse and excessive use of the Internet; the so-called 'information smog', i.e. access to too much information that can cause difficulties in selecting the right one; the inability to distinguish true information from information that appears to be credible (fake news); students' access to morally unacceptable values; Internet commerce; the problem of identity in the situation of 'virtual exposure'; Internet addiction; violence in computer games; impairment of language skills of students and many others. ${ }^{13}$ Widespread access to computers and the Internet poses an increasing threat to children and young people unless proper education is provided in this regard. Teachers of religious education should also be involved as the information society in which they live requires their competence in information technology. These competences allow them not only to use technology to attractively convey the Gospel message during classes at school, but also to educate students in the proper, wise and ethical use of technology. The role of RE teachers is to equip young people with the skills necessary for their proper functioning in the information society and to familiarize them with the possibilities of applying new technologies also in the work of evangelization. An RE teacher must therefore have the appropriate knowledge and skills to prepare his/her students for living in a changing reality.

${ }^{12}$ Cf. M. Golka, Czym jest społeczeństwo informacyjne?, "Ruch Prawniczy, Ekonomiczny i Socjologiczny" (2005) No 4, pp. 259-260.

${ }^{13}$ Cf. A. Siemińska-Łosko, Negatywne implikacje wprowadzenia technologii informacyjnej do edukacji, in Wybrane aspekty technologii informacyjnej w edukacji, D. Siemieniecka, A. Siemińska-Łosko (eds.), Toruń 2007, pp. 86-106. 


\section{Requirements for the Information Technology Competence of RE Teachers in the Professional Advancement Procedure}

In the first years of political transformation in Poland, one of the most crucial issues was the reform of education. At that time, it was also important for the Catholic Church to restore the teaching of Religious Education in schools. In the People's Republic of Poland, the place of Religious Education changed several times after World War II. Due to the changing legal status, it was removed from schools at first, later it was restored for a short time to be finally removed after the adoption of the Act of 15 July 1961 on the development of the education system, stating that schools and educational establishments are secular institutions. ${ }^{14}$ Teachers of Catholic religious education, both clergy and laymen, lost their employee rights granted at that time to teachers employed in schools. This situation changed in the 1990-1991 school year, when Religious Education returned to schools and kindergartens becoming an integral part of the state education system. The teacher of Religious Education in Poland henceforth has the same rights and obligations as teachers of compulsory subjects. ${ }^{15}$ This follows from the Regulation of the Minister of National Education of April 14, 1992 on the conditions and method of organizing religious education in state schools ${ }^{16}$ : "Teachers are employed in accordance with the Teacher's Charter" s 5(4).

An important matter for the issues discussed in this paper was the amendment to the Teachers' Charter in $2000^{17}$, which introduced a multi-stage professional advancement procedure for teachers, which was henceforth a vital mechanism for improving their work, the quality of education and functioning of schools. The Act did not specify additional requirements for RE teachers due to the specific nature of the subject. There were also no arrangements

${ }^{14}$ Cf. A. Mezglewski, Usunięcie i przywrócenie nauczania religii do szkół, in: Katecheza dzisiaj. Problemy prawne i teologiczne, W. Janiga, A. Mezglewski (eds.), Krosno - Sandomierz 2000, pp. 97-104.

15 Participation of students in classes of RE in schools in Poland is not obligatory. Parents decide whether to enroll a child in RE classes, and students who are eighteen years old take the decision themselves.

${ }^{16}$ The Regulation of the Minister of National Education of 14 April 1992 on the Conditions and Manner of Organizing Religious Education in Public Schools, Journal of Laws 1992, No. 36 item 155.

17 The amendment to the Teacher's Charter Act consisted in adding a new text of several pages entitled "Chapter 3a - Teachers - Professional Advancement". 
in this regard between the Ministry of National Education and the Commission of Catholic Education of the Polish Episcopate. Therefore, there are no separate criteria in Poland regarding the professional development of RE teachers; the same regulations apply to them as to the teachers of other subjects. ${ }^{18}$

The amended Teachers' Charter introduced a four-level hierarchy of grades in the professional advancement of teachers in Poland: trainee teacher, contract teacher, appointed teacher and chartered teacher. ${ }^{19}$ On entering the teaching profession, a new teacher has the status of trainee teacher, and must attain subsequent grades by meeting the requirements set out in the Regulation of the Minister of National Education of August 3, 2000 on the career progression of teachers. Attaining the next grade in the hierarchy of professional advancement requires from a teacher to undergo a period of in-service training, which in the case of teachers applying for the contract teacher grade is 9 months, and in the case of teachers applying for the grade of appointed teacher and chartered teacher is 2 years and 9 months each. During the in-service training period, the teacher carries out tasks according to his/her own professional development plan; they result both from the provisions of the regulation, the specific nature of the subject taught and the type of school. After completing the in-service training period, in order to pass it and obtain the grade, the teacher submits a written report to the school head. When the assessment is positive, the next step is the teacher's written request to establish one of three committees:

- a qualifying committee for the trainee teacher applying for the grade of contract teacher; the committee conducts a conversation with the teacher during which he/she presents a report on the implementation of the professional development plan and answers questions of the committee members regarding the qualification requirements enabling him/her to obtain professional promotion to the grade of contract teacher, as specified in s 3(2) of the Regulation;

- an examination panel for contract teachers applying for the grade of appointed teacher; the committee conducts an examination during which the teacher presents his/her own professional achievements and answers questions of the committee members regarding examina-

${ }^{18}$ Cf. W. Janiga, System awansu zawodowego nauczycieli, in: Katecheza dzisiaj. Problemy prawne i teologiczne, W. Janiga, A. Mezglewski (eds.), Krosno - Sandomierz 2000, pp. 148-149.

${ }^{19}$ A four-level system of professional advancement of teachers applies to Croatia, Lithuania, Hungary, Romania, Slovenia, Slovakia, Scotland, Albania and Poland. 
tion requirements enabling him/her to obtain professional promotion to the grade of appointed teacher specified in s 4(2) of the Regulation;

- a qualifying committee for the appointed teacher applying for the degree of chartered teacher; the committee examines and evaluates the documentation provided by the teacher, in which he or she presents the report of qualification requirements enabling him/her to be promoted to the grade of chartered teacher, as specified in s 5(2) of the Regulation.

An important element in obtaining the next grade of professional advancement is the preparation of relevant documentation by teachers. It is mandatory because the teacher is required to draw up his/her own professional development plan for the duration of the in-service training period, and after completion to write a report on its implementation. This requirement imposes on the teacher a systematic approach to documenting his/her own activities, as well as self-reflection and evaluation of his/her own work.

The regulation specifying the professional development procedures for teachers indicates the tasks that the teacher should perform during the in-service training period and the requirements necessary to obtain a given grade of professional development. An analysis of these tasks and requirements demonstrates that very general conditions have been set for teachers in the area of information technology competences. They were not included at the stage of applying for the grade of contract teacher and were formulated among the examination requirements enabling teachers to be promoted to the grade of appointed teacher. The regulation contained a provision which stated that the teacher should have "the ability to use computer and information technology in his/her work" - s 4(2) (4). However, the teacher applying for the grade of chartered teacher must meet the qualification requirement related to "the development and implementation of projects and programs for the improvement of their work and the quality of school work, including the use and improvement of computer and information technology skills" - s 5(2)(1). Nevertheless, the regulation did not specify which particular skills were required and they were generally defined as computer and information technology, which allowed teachers to freely interpret the provisions of the regulation and to use the technology to varying degrees both at the stage of preparation for the lesson and in work with students at school.

In the light of the aforementioned provisions of the regulation, it can be seen that teachers were required to improve the skills they should have acquired during their university studies. The Regulation of the Minister of National 
Education and Sport of September 23, 2003 specifying teacher education standards ${ }^{20}$ imposed on universities the obligation to provide students with information technology and communication competences, expressed in the ability to use technology and apply it in teaching. It should be noted here that there are no separate provisions for the education of prospective teachers of Religious Education. There are only recommendations, or rather suggestions, regarding the improvement of professional qualifications of RE teachers in their professional development. This is to be helped by the activities of diocesan catechetical reports, whose task is to inform RE teachers about "current legislative arrangements and to create a broad forum for exchanging views, so that they too can have the opportunity to have some influence on the determination of their legal status in school." ${ }^{21}$

Requirements for attaining further grades of professional advancement did not motivate teachers sufficiently to deepen their knowledge and develop skills necessary in the constantly evolving information society. Lack of verification of these skills by the members of the examination committee, made it impossible to assess the actual skills of teachers. Therefore, the amendment to the Regulation of the Minister of National Education of 26 July 2018 on attaining grades of professional advancement by teachers is crucial for the issues discussed ${ }^{22}$ since at each stage of professional development, teachers are required to obtain competences in information and communication technology:

- a trainee teacher applying for the grade of contract teacher should be "able to use multimedia and IT tools at work, especially during classes" - s 6(2)(6);

- a contract teacher applying for the grade of appointed teacher should be "able to use multimedia and IT tools at work, especially during classes" - s 7(2)(8);

- an appointed teacher applying for the grade of chartered teacher should be "able to use activating methods at work as well as multimedia and IT tools conducive to the learning process" - s 8(3)(1).

20 The Regulation of the Minister of National Education and Sport of 23 September 2003 on the Standards of Teacher Education, Journal of Laws 2003, No. 170, item 1655.

${ }^{21}$ Konferencja Episkopatu Polski, Dyrektorium katechetyczne Kościoła katolickiego w Polsce, Kraków 2001, p. 107.

22 The Regulation of the Minister of National Education of 26 July 2018 on the Professional Promotion Degrees for Teachers, Journal of Laws 2018, item 1574. 
The professional advancement procedure amended in 2018 makes it possible to verify and assess the skills of trainee teachers and contract teachers, because they have to perform a task using multimedia tools in the presence of a qualifying or examination committee (s 12(1)(2 b) of the Regulation). Such requirements are not imposed on applicants for the grade of chartered teachers. They are, however, obliged to present to the committee a method of implementation of a task selected by them as specified in the regulation s 8(3) and they frequently do it in the form of a multimedia presentation.

Due to the confidential mode of the committee's proceedings, it is impossible to examine what the actual level of teachers' information and communication competences is at individual stages of professional advancement and to what extent it is adequate to the requirements of the information society. There is also a lack of comprehensive research on the information competences of teachers of RE in Poland; so far only research on three archdioceses (Warmia, Poznań and Lublin $)^{23}$ has been conducted. However, the results of the large-scale research conducted by the team under the supervision of Marlena Plebańska in June 2017 are available on the Internet, the purpose of which was a comprehensive diagnosis of the state of application of information and communication technology in schools, in relation to the entire school environment. They prove that technology is used in all lessons, including Religious Education classes. The research results were developed by a team of researchers from the Faculty of Education of the University of Warsaw in collaboration with the consulting company Public Consulting Group (PCG Education) and made available in the form of a report "The Polish School in the Age of Digitization. Diagnosis 2017". It shows, among others, that in about half of Polish schools modern technologies are present, although they are primarily applied for demonstrative presentation of content by teachers rather than activating students. Most schools make use of computer and multimedia boards, but only a few respondents (2\%) use tablets. Among the digital resources utilized in Polish schools, multimedia presentations predominate and to a lesser extent multimedia materials such as films, animations and graphic materials. The application of new technologies does not exert a profound influence on the organization and course of the lesson,

23 A. Bielinowicz, Rozwój kompetencji informatycznych nauczycieli religii w archidiecezji warmińskiej, Olsztyn 2020; J. Staniś-Rzepka, Nowe technologie informacyjne w posłudze katechetycznej, PhD disseration, Poznań 2019; A. Szajda, Kompetencje medialne nauczycieli religii archidiecezji lubelskiej $w$ świetle dokumentów Kościoła $i$ badań własnych. Studium z edukacji medialnej, PhD disseration, Lublin 2018. 
as expository methods still dominate, which indicates that the view of teaching as transmission is prevalent in education. ${ }^{24}$

\section{Conclusions}

The sphere of professional competence of the teacher can be developed and blocked, both in the volitive sphere and by external circumstances and factors. The positive motivation of the teacher to implement information and communication technology in his/her work may be weakened or even prevented by the belief that while it is theoretically desirable, it is practically impossible, for example due to the lack of appropriate equipment at school, lack of Internet access, etc. The need to fulfill the imperative of the law and the imposed regulation may not only discourage some teachers from developing professionally, but also lead to frustration that their motivation is solely directed by the letter of the law. On the other hand, the system of professional advancement proposed by the Ministry of National Education in 2000 should be considered a "very effective stimulator" in raising teachers' competences ${ }^{25}$, also in the area of IT. Should these qualifications be considered sufficient in view of the challenges of a rapidly growing information society? Certainly not. The teacher of Religious Education, like teachers of other subjects, must be a person who notices, correctly diagnoses and evaluates the changes he/she witnesses. Czesław Banach emphasizes that "all generations of teachers will face a difficult process of adaptation to social and political changes, Europeanization and globalization of life, as well as the shaping of the information and democratic society, which is open, critical and creative." ${ }^{26}$ This requires from teachers of all subjects high competence in the use of information and communication technology at school. The direction of extending these competences is indicated by the report A Framework for Developing and Understanding Digital Competence in Europe, known as DigComp 1.o. The document was developed by the Joint Research Center of the European Commission, published for the first time in 2013, and then updated in June 2016

${ }^{24}$ Cf. Plebańska M., Polska szkoła $w$ dobie cyfryzacji. Diagnoza 2017, https://www. cyfrowobezpieczni.pl/uploads/filemanager/raporty/RAPORT_CYFRYZCJA_SZKOL_2017. pdf (20.03.2020).

${ }^{25}$ Cf. J. Kowalikowa, Zawód nauczyciela w świetle reformy, in: Kompetencje nauczycieli w reformowanej szkole, M. T. Michalewska, P. Kowalik (eds.), Katowice 2003, pp. 15, 17.

${ }^{26}$ Cz. Banach, Nauczyciel naszych oczekiwań i potrzeb od A do Ż, Lublin 2009, p. 10. 
(DigComp 2.o). What the report highlights are IT competences in the modern world; it is not only knowledge in the field of information and communication technology that is important, but also the right skills and the right attitudes towards the challenges of the information society. DigComp 2.0 indicates five areas of such competences:

1. Information and data literacy (browsing, searching and filtering data, information and digital content; evaluating data, information and digital content; managing data, information and digital content).

2. Communication and collaboration (interacting through digital technologies; sharing through digital technologies; engaging in citizenship through digital technologies; collaborating through digital technologies; netiquette; managing digital identity).

3. Digital content creation (developing digital content; integrating and re-elaborating digital content; copyright and licenses; programming).

4. Safety (protecting devices; protecting personal data and privacy; protecting health and well-being; protecting the environment).

5. Problem solving (solving technical problems; identifying needs and technological responses; creatively using digital technologies; identifying digital competence gaps). ${ }^{27}$

A Framework for Developing and Understanding Digital Competence in Europe also emphasizes professional programs for teachers applied in various European Union countries, for example in Spain, Lithuania, Portugal, Norway and Croatia. ${ }^{28}$ They can be a valuable inspiration for the Ministry of National Education in Poland not only in designing the model of professional advancement, but also in supporting teachers in developing information competences.

Bearing in mind the rapid development of technology, it should be postulated to channel the requirements imposed on teachers in the sphere of their professional advancement into developing competences related to the use of mobile devices in education. In Poland, teachers have low awareness of the possibility of applying such devices in school, largely limited to the use of mobile phones/ smartphones, which in my opinion should not be utilized as teaching tools. RE teachers, like teachers of other subjects, are not familiar with iPads and how

${ }^{27}$ Cf. R. Vuorikari, Y. Punie, S. Carretero, L. van den Brande, DigComp 2.0: The Digital Competence Framework for Citizens, 2016, pp. 14-18.

28 Cf. R. Vuorikari, Y. Punie, S. Carretero, L. van den Brande, DigComp 2.0: The Digital Competence Framework for Citizens, 2016, p. 23. 
to apply them in education, despite the fact that 10 years have passed since the launch of these tablets in the USA. Research on the use of iPads in Religious Education classes conducted at the Faculty of Theology of Nicolaus Copernicus University in Torun meets these needs. ${ }^{29}$ The directions of changes that are taking place in Polish schools also condition the transformation in the teaching of Religious Education. They place new and increasing demands on RE teachers, among others, in the area of information competences.

\section{Bibliography}

Act of 25 July 1998 amending the School Education Act, Journal of Laws 1998, No 117, item 759.

Act of 8 January 1999 - The School System Reform Act, Journal of Laws 1999, No 12, item 96.

Banach Cz., Nauczyciel naszych oczekiwań i potrzeb od A do Ż, Lublin 2009.

Bielinowicz A., Rozwój kompetencji informatycznych nauczycieli religii $w$ archidiecezji warmińskiej, Olsztyn 2020.

Bilicka B., Gurzyński M., iPad na szkolnych lekcjach religii, Torun 2019.

Goban-Klas T., Spoleczeństwo informacyjne i jego teoretycy, in: $W$ drodze do społeczeństwa informacyjnego, J. Lubacz (ed.), Warszawa 1999.

Goban-Klas T., Sienkiewicz P., Społeczeństwo informacyjne: szanse, zagrożenia, wyzwania, Kraków 1999.

Golka M., Czym jest społeczeństwo informacyjne?, "Ruch Prawniczy, Ekonomiczny i Socjologiczny" (2005) No 4, pp. 253-265.

Górski A., Procesy powstawania, przetwarzania i wykorzystywania wiedzy w spoleczeństwie informacyjnym, "Studia Informatica Pomerania" (2017) No 4, pp. 19-34.

Janiga W., System awansu zawodowego nauczycieli, in: Katecheza dzisiaj. Problemy prawne i teologiczne, W. Janiga, A. Mezglewski (eds.), Krosno - Sandomierz 2000, pp. 141-149.

Konferencja Episkopatu Polski, Dyrektorium katechetyczne Kościoła katolickiego w Polsce, Kraków 2001.

Kordek A. Zastosowanie iPada jako podręcznika do nauki religii, in: Katecheta i katechizowany w Sieci, B. Bilicka (ed.), Toruń 2015, pp. 113-144.

Kordek A., Platforma edukacyjna Apple w szkolnym nauczaniu religii, in: Katecheta

${ }^{29}$ B. Bilicka, M. Gurzyński, iPad na szkolnych lekcjach religii, Toruń 2019; A. Kordek, Zastosowanie iPada jako podręcznika do nauki religii, in: Katecheta i katechizowany w Sieci, B. Bilicka (ed.), Toruń 2015, pp. 113-144; A. Kordek, Platforma edukacyjna Apple w szkolnym nauczaniu religii, in: Katecheta i katechizowany w Sieci, B. Bilicka (ed.), Toruń 2015, pp. 163-200. 
i katechizowany w Sieci, B. Bilicka (ed.), Toruń 2015, pp. 163-200.

Kowalikowa J., Zawód nauczyciela w świetle reformy, in Kompetencje nauczycieli $w$ reformowanej szkole, M. T. Michalewska, P. Kowalik (eds.), Katowice 2003.

Mezglewski A., Usunięcie i przywrócenie nauczania religii do szkół, in: Katecheza dzisiaj. Problemy prawne i teologiczne, W. Janiga, A. Mezglewski (eds.), Krosno - Sandomierz 2000, pp. 97-108.

Plebańska M., Polska szkoła $w$ https://www.cyfrowobezpieczni.pl/uploads/filemanager/ raporty/RAPORT_CYFRYZCJA_SZKOL_2017.pdf (20.06.2020).dobie cyfryzacji. Diagnoza 2017,

Siemińska-Łosko A., Negatywne implikacje wprowadzenia technologii informacyjnej do edukacji, in Wybrane aspekty technologii informacyjnej w edukacji, D. Siemieniecka, A. Siemińska-Łosko (eds.), Toruń 2007, pp. 86-106.

Staniś-Rzepka J., Nowe technologie informacyjne w posłudze katechetycznej, PhD disseration, Poznań 2019.

Szajda A., Kompetencje medialne nauczycieli religii archidiecezji lubelskiej $w$ świetle dokumentów Kościoła i badań własnych. Studium z edukacji medialnej, PhD disseration, Lublin 2018.

The Regulation of the Minister of National Education of 14 April 1992 on the Conditions and Manner of Organizing Religious Education in Public Schools, Journal of Laws 1992, No. 36 item 155.

The Regulation of the Minister of National Education of 3 August 2000 on the Acquisition of Teachers' Professional Titles, Journal of Laws 2000, No. 70, item 825.

The Regulation of the Minister of National Education and Sport of 23 September 2003 on the Standards of Teacher Education, Journal of Laws 2003, No. 170, item 1655.

The Regulation of the Minister of National Education of 26 July 2018 on the Professional Promotion Degrees for Teachers, Journal of Laws 2018, item 1574.

The Teachers' Charter Act of 18 February 2000, Journal of Laws 2000, No 19, item 239.

Vuorikari R., Punie Y., Carretero S., L. van den Brande, DigComp 2.0: The Digital Competence Framework for Citizens, 2016.

Zalewska - Bujak M., Udział nauczycieli w przemianach edukacyjnych przełomu XX $i$ XXI stulecia $w$ Polsce, Katowice 2010. 